\title{
Anisocytosis and the C-1000 Channelyzer in macrocytic anaemia
}

\author{
S. J. PROCTOR, J. R. COX, AND T. J. SHERIDAN \\ From the Department of Haematology, Royal Victoria Infirmary, Newcastle upon Tyne
}

SYNOPSIS Red cell anisocytosis as assessed using the Coulter Channelyzer C-1000 showed an increase with progressive anaemia in 25 patients with macrocytosis due to $\mathrm{B}_{\mathbf{1 2}}$ and/or folate deficiency. In deficiency of a single factor, the degree of anisocytosis increased with progressive anaemia. In five cases with $\mathrm{B}_{12}$ and folate deficiency combined, anisocytosis was markedly increased out of proportion to the degree of anaemia present. Iron stores were also reduced in four of these cases. It is suggested that objective measurement of anisocytosis is of early diagnostic value in the assessment of multiple haematinic factor deficiency, for example, in macrocytic anaemia associated with malabsorption states and unexpected multiple deficiency states.

The uses of the Coulter Channelyzer C-1000 in the assessment of cell populations based on cell volume are well known (Hughes-Jones et al, 1974). Preliminary studies have suggested potential uses of the technique in investigation of red cell populations in various haematological conditions (England and Down, 1974; Bessman and Johnson, 1975). We have undertaken a survey of the techniques as an objective measurement of anisocytosis in macrocytosis due to megaloblastic factor deficiency in 25 consecutive patients. Patients with macrocytosis associated with liver disease, drugs (eg, antimetabolites) or other specific haematological conditions associated with macrocytosis were excluded.

\section{Methods}

Red cell volume distribution curves were obtained by diluting whole blood collected into EDTA anticoagulant and diluted in Isoton approximately 1 in 70000 to give a red cell count on the Coulter Model ZF of between 20000 and $30000 / 0.5 \mathrm{ml}$, ie, before the $10 \%$ coincidence limit.

Coulter Counter Model ZF (orifice $100 \mathrm{u}$; attenuation 0.354; aperture 16) was connected to a Coulter Channelyzer C-1000 (window width (WW) 100; base channel threshold (BCT) $\mathrm{O}$ edit switch on; stop at full-scale deflection $1 \mathrm{~K}$ ). These settings allow the use of the basic 100 channels, therefore the volume of cells in each channel (C) was obtained from the product of $\mathrm{C}$ and the threshold factor. The Received for publication 23 January 1976 latter was estimated by calibrating the instrument using Coulter 4C samples of known mean cell volume (MCV). The mean cell channel was obtained using Simpson's rule (Coulter C-1000 Channelyzer Manual, p. 32). The mean channel in which the cells appeared was directly proportional to the MCV. The basic channel numbers were then converted into volumes (fl) by multiplying by 1.86 (threshold factor).

Additional checks on the machine were made by repeating the calculations using pig red cells and macrocytic human red cells, the MCVs of which were calculated on the Coulter Model S, and from haematocrit measurements and manual red cell counts. From these results the Channelyzer appeared linear between $50 \mathrm{fl}$ and $140 \mathrm{ff}$.

Haemoglobin and MCV values shown in tables I and II were obtained using a Coulter Counter Model S standardized on $4 \mathrm{C}$ and using the DHSS National Quality Control programme. The patients were considered to be deficient in $\mathrm{B}_{12}$ when serum values were less than $160 \mathrm{ng} /$ litre (Britt et al, 1969). Double isotope Schilling Tests (Dicopac) were used as an additional diagnostic aid to differentiate pernicious anaemia and malabsorption states. Folate status was assessed by red cell and serum folate estimations (Herbert, 1966); folate deficiency was diagnosed when red cell folate was less than $180 \mathrm{ng} / \mathrm{ml}$ and serum folate less than $3 \mathrm{ng} / \mathrm{ml}$.

Iron stores were assessed by examination of stained marrow smears and by measurement of serum iron (Technicon AutoAnalyser Methodology) and iron 


\begin{tabular}{|c|c|c|c|c|c|c|c|}
\hline & Diagnostic Category & $\operatorname{Sex}$ & $\begin{array}{l}H b \\
(g / d l)\end{array}$ & $\begin{array}{l}M C V \\
(f)\end{array}$ & Haematinic Deficiency & $\begin{array}{l}\text { Volume Range } \\
\text { of } 95 \% \text { Cells }\end{array}$ & $\begin{array}{l}\text { Volume Ratio } \\
\text { of } 95 \% \text { Cells }\end{array}$ \\
\hline 1 & PA diet folate & $\mathbf{F}$ & $6 \cdot 3$ & 122 & $B_{12}+$ folate & 131 & $4 \cdot 64$ \\
\hline 2 & PA & $\mathbf{F}$ & $7 \cdot 0$ & 105 & $\mathrm{~B}_{12}$ & 105 & $2 \cdot 98$ \\
\hline 3 & PA & $\mathrm{M}$ & $8 \cdot 0$ & 140 & $B_{12}$ & 84 & 1.97 \\
\hline 4 & PA & $\mathrm{F}$ & $8 \cdot 5$ & 106 & $\mathbf{B}_{12}+$ iron & 83 & $2 \cdot 26$ \\
\hline 5 & PA & $\mathbf{F}$ & $10 \cdot 2$ & 110 & $\mathbf{B}_{12}$ & 84 & $2 \cdot 72$ \\
\hline 6 & PA & $\mathbf{M}$ & $10 \cdot 2$ & 114 & $\mathbf{B}_{12}$ & 80 & $2 \cdot 17$ \\
\hline 7 & PA & $\mathrm{F}$ & $10 \cdot 4$ & 124 & $\mathbf{B}_{12}$ & 97 & $2 \cdot 44$ \\
\hline 8 & PA & $F$ & $10 \cdot 8$ & 117 & $\mathrm{~B}_{12}$ & 74 & 1.95 \\
\hline 9 & $\mathbf{P A}+\mathbf{S C D}$ & $\mathrm{F}$ & $12 \cdot 7$ & 130 & $\mathrm{~B}_{12}$ & 74 & 1.86 \\
\hline 10 & PA & $\mathbf{F}$ & 13.0 & 113 & $\mathrm{~B}_{12}+$ ?iron & 94 & $2 \cdot 38$ \\
\hline 11 & $\mathbf{P A}+\mathbf{S C D}$ & $\mathbf{M}$ & $13 \cdot 9$ & 107 & $\mathrm{~B}_{12}$ & 65 & 1.95 \\
\hline 12 & PA & $\mathrm{F}$ & $14 \cdot 3$ & 111 & $\mathbf{B}_{12}+$ ? iron & 61 & 1.82 \\
\hline 13 & Coeliac-untreated & $\mathrm{F}$ & $4 \cdot 0$ & 102 & $\mathrm{~B}_{12}$, folate, iron & 124 & $3 \cdot 88$ \\
\hline 14 & Coeliac-untreated & $\mathbf{M}$ & $7 \cdot 6$ & 108 & $B_{12}$, folate, iron & 109 & $3 \cdot 23$ \\
\hline 15 & Coeliac-untreated & $\mathbf{F}$ & $8 \cdot 4$ & 112 & $\mathbf{B}_{12}$, folate, iron & 113 & $3 \cdot 54$ \\
\hline 16 & Coeliac-untreated & $\mathbf{F}$ & $8 \cdot 5$ & 122 & $\mathrm{~B}_{12}$, folate, iron & 139 & $4 \cdot 48$ \\
\hline 17 & Coeliac-treated & $\mathrm{F}$ & $10 \cdot 7$ & 114 & Folate + iron & 95 & $2 \cdot 55$ \\
\hline 18 & Coeliac-treated & $\mathbf{M}$ & $11 \cdot 7$ & 107 & Folate & 82 & 2.40 \\
\hline 19 & Coeliac-treated & $\mathbf{F}$ & 13.0 & 114 & Folate & 81 & $2 \cdot 16$ \\
\hline 20 & Dietary deficiency & $\mathbf{F}$ & $6 \cdot 1$ & 118 & Folate & 100 & 2.65 \\
\hline 21 & Dietary deficiency & $\mathbf{F}$ & 10.9 & 112 & Folate & 85 & $2 \cdot 20$ \\
\hline 22 & ? Dietary & $\mathbf{F}$ & $11 \cdot 2$ & 120 & $\mathbf{B}_{12}+$ iron & 78 & $2 \cdot 00$ \\
\hline 23 & ? Dietary & $F$ & 13.7 & 109 & Folate & 73 & $2 \cdot 00$ \\
\hline 24 & Crohn's disease & $\mathbf{F}$ & $11 \cdot 3$ & 126 & $\mathrm{~B}_{12}$ & 76 & 1.90 \\
\hline 25 & Ileal resection & $\mathbf{M}$ & $11 \cdot 0$ & 112 & $\mathrm{~B}_{12}$ & 78 & $2 \cdot 10$ \\
\hline
\end{tabular}

Table I Relevant haematological information in varying diagnostic groups

Pernicious anaemia ( 12 cases) was the commonest single cause of macrocytic anaemia in these consecutive cases. Untreated coeliac patients ${ }^{\circ}$ with multiple haematinic factor deficiencies exhibit markedly increased volume range and ratio when compared with the single deficiencies. These four cases, however, cannot be distinguished from the remainder on the basis of the MCV.

$\mathbf{P A}=$ pernicious anaemia $; \mathbf{S C D}=$ subacute combined degeneration.

\begin{tabular}{|c|c|c|c|c|c|c|}
\hline \multirow[b]{2}{*}{ No. of Cases } & \multicolumn{3}{|l|}{ Normals } & \multicolumn{3}{|l|}{ Patients } \\
\hline & $\begin{array}{l}20 \\
M C V \\
(f)\end{array}$ & $\begin{array}{l}\text { Volume } \\
\text { Range }\end{array}$ & $\begin{array}{l}\text { Volume } \\
\text { Ratio }\end{array}$ & $\begin{array}{l}25 \\
M C V \\
(f l)\end{array}$ & $\begin{array}{l}\text { Volume } \\
\text { Range }\end{array}$ & $\begin{array}{l}\text { Volume } \\
\text { Ratio }\end{array}$ \\
\hline Mean & $\begin{array}{l}89 \cdot 7 \\
(84-94)\end{array}$ & $\begin{array}{l}54 \cdot 26 \\
(48-63)\end{array}$ & $\begin{array}{l}1 \cdot 91 \\
(1 \cdot 7-2 \cdot 15)\end{array}$ & $\begin{array}{l}115 \\
(102-140)\end{array}$ & $\begin{array}{l}90 \cdot 8 \\
(60-139)\end{array}$ & $\begin{array}{l}2 \cdot 55 \\
(1 \cdot 82-4 \cdot 48)\end{array}$ \\
\hline SD & $3 \cdot 24$ & $3 \cdot 51$ & 0.11 & 8.47 & 20.08 & 0.80 \\
\hline
\end{tabular}

Table II MCV values from the Coulter Counter Model $S$

Values for the volume range and ratio of $95 \%$ cells in normals are similar to those found by previous workers (England and Down, 1974).

binding capacity (van der Wal, 1972). When the serum iron was less than $13 \mu \mathrm{mol} / \mathrm{litre}$ in association with reduced marrow iron stores, deficiency of this haematinic was diagnosed.

The diagnosis of coeliac disease was confirmed by jejunal mucosal biopsy. In the patient group the presence of liver disease was excluded on the basis of clinical findings and routine liver function tests. Twenty normal controls (10 male and 10 female) had full blood counts, and distribution curves were calculated as above.

\section{Results}

Anisocytosis has been numerically assessed by considering the difference in volumes of $95 \%$ of the cell population. These volumes are obtained by plotting the cumulative frequencies on log prob-윽 ability paper against cell volume. The volumes of $\rightarrow$ $2.5 \%$ and $97.5 \%$ of cells can then be assessed (England and Down, 1974). The volume difference $N$ between the upper and lower limit is designated by the volume range, and the volume of the largest cell 0 divided by that of the smallest is the volume ratio. $\omega$ These data plus other relevant haematological? parameters are shown in tables I and II.

Figure 1 demonstrates the variation in anisocytosis as represented by volume ratio to the level $\stackrel{\infty}{+}$ of haemoglobin. In combined $B_{12}$ and folate deficiency, the degree of anisocytosis is grossly enhanced. The details of four such curves (patients $\stackrel{\mathbb{P}}{\mathscr{P}}$ $1,14,15,16)$ are shown in figure 2B-E. In comparison $\stackrel{\unrhd}{\varrho}$ a case of pernicious anaemia shown in fig $2 \mathrm{~A}$ has only moderate anisocytosis. 


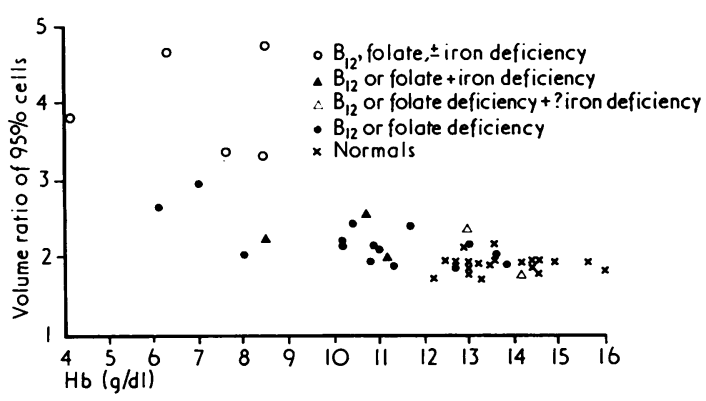

Fig 1 Variation in anisocytosis as represented by volume ratio to the level of haemoglobin. In $B_{12}$ or folate deficiency and $B_{12}$ or folate plus iron deficiency, the anisocytosis increases gradually as the haemoglobin falls. In the five cases with $B_{12}$ and folate deficiency, anisocytosis is increased out of proportion to the degree of anaemia when compared with those cases of pernicious anaemia with similar haemoglobin levels

Bone marrow examination in 18 patients revealed varying degrees of megaloblastic change, depending upon the level of haemoglobin. In those with relatively normal haemoglobin at the outset, the only change noted during treatment was gradual improvement of MCV values. The response to appropriate haematinic therapy was used as an additional check on initially diagnosed deficiencies. Patients with coeliac disease were treated with a gluten-free diet and the appropriate haematinics.

\section{Discussion}

Red cell morphology is routinely assessed microscopically and rightly is considered of paramount importance in diagnostic haematology. Recent workers (England and Down, 1974; Bentley and Lewis, 1975) have stressed the problems of objectively analysing and recording these microscopic parameters. The same workers, using electronic particle sizers and analysing computers respectively, have attempted to quantify red cell anisocytosis. The methods employed have exciting possibilities and give similar information to the original PriceJones technique but have the advantages of accuracy and speed.

The use of electronic particle counters in this field have made it possible to construct cell volume distribution curves by pulse height analysis (Ur and Lushbaugh, 1968; Lushbaugh et al, 1962). The more recent addition of the $\mathrm{C}-1000$ Channelyzer linked to routine Coulter Counters enables red cells to be placed in distribution curves according to volume.
These curves are very reproducible, and permanent records of many abnormal blood film appearances can be made in less than half a minute (Bessman and Johnson, 1975).

Previous reviews have suggested that anisocytosis increased in megaloblastic states with progressive anaemia (Chanarin, 1969). Our data confirm the finding that in single $\mathrm{B}_{12}$ or folate deficiency, anisocytosis does increase as the haemoglobin falls. In the four cases with low serum iron associated with $B_{12}$ or folate deficiency, there were variable increases in the degree of anisocytosis. Of these cases, two had relatively normal haemoglobins (cases 10 and 12) but had low serum irons associated with low ironbinding capacities and normal marrow iron stores, which suggests that true iron deficiency was not present. The degree of anisocytosis was not increased in these two patients. In the case of coeliac disease associated with folate deficiency and marked iron deficiency, anisocytosis was increased out of proportion to the degree of anaemia (case 17).

Striking anisocytosis was seen in five cases in whom both $\mathrm{B}_{12}$ and folate were deficient. A very low serum iron level, high iron-binding capacity, and reduced marrow iron stores were found in four of these cases, all of whom had coeliac disease which presented with atypical features, ie, absence of overt bowel disturbance. The details of four of these distribution curves compared to a typical single deficiency distribution curve are shown in figure 2A-E. The five cases with gross anisocytosis have a markedly increased volume ratio out of proportion to the degree of anaemia. We suggest that when such curves are obtained in these circumstances it should alert the operator to the possibility of a deficiency of two factors with or without additional iron deficiency. There is no correlation of $\mathrm{MCV}$, as measured on the Coulter $S$, to the degree of anaemia or to the degree of anisocytosis (table I). Those patients with double deficiencies could not be distinguished from single deficiency states on the basis of mean cell volume. We confirm that the volume range and, in particular, the volume ratio of $95 \%$ of cells is a satisfactory measure of anisocytosis.

In our experience, the only additional clinical situation where gross anisocytosis has been seen was in a case of hepatic coma associated with alcoholic cirrhosis. In this situation serum $\mathbf{B}_{12}$, folate, and iron levels were within normal limits in the presence of a macrocytic anaemia.

Our conclusion is that the technique provides the facility for objective measurement of red cell anisocytosis. It can be of diagnostic value in early assessment of macrocytic anaemia due to multiple haematinic deficiency in patients in whom liver disease is not present as a complementary factor. 


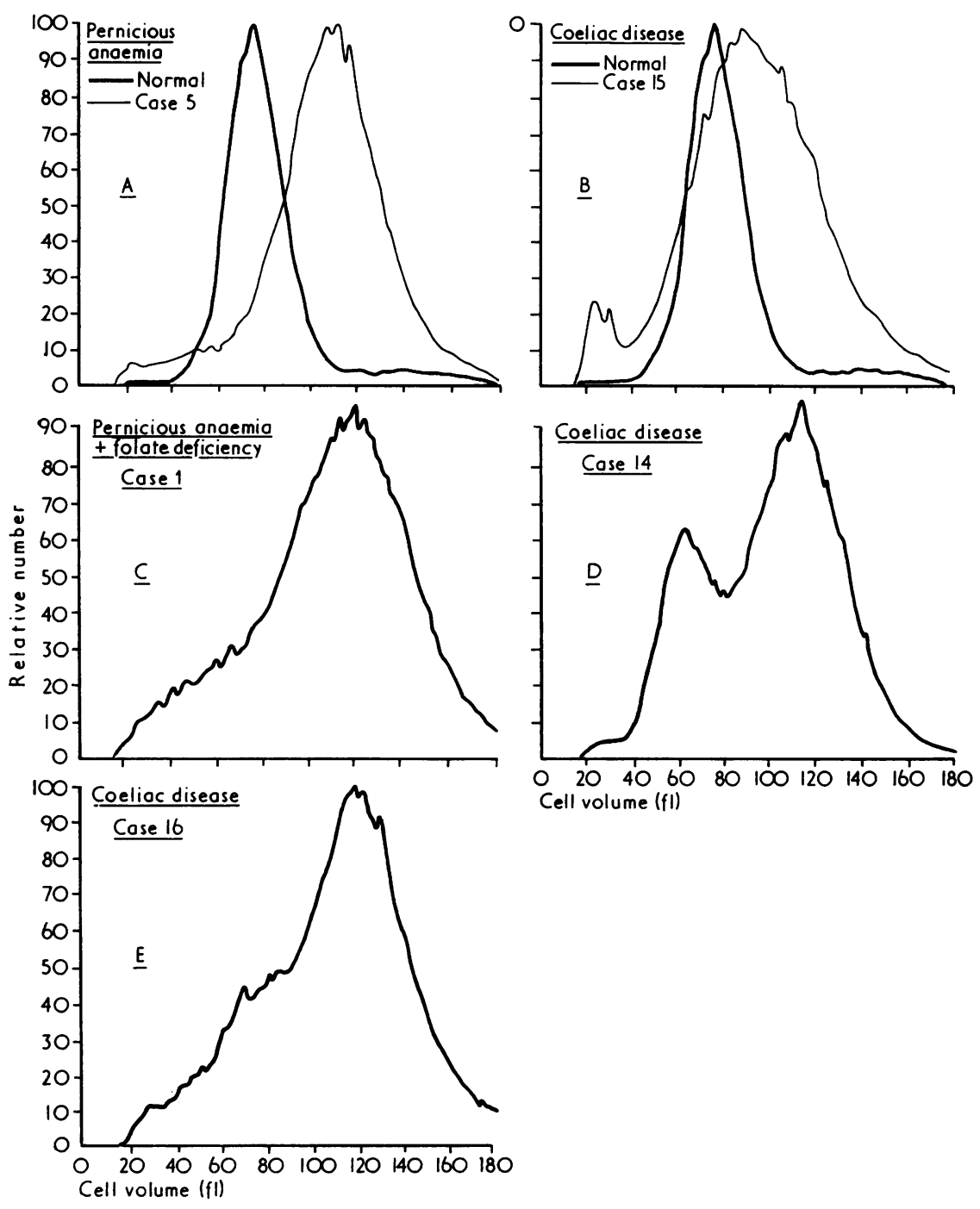

Fig 2 (A) Red cell distribution curve in a case of pernicious anaemia. There is a moderate anisocytosis when compared to a normal control although less than that seen in multiple deficiencies. (B) Red cell distribution curve in a case of coeliac disease presenting as a macrocytic anaemia without typical gastrointestinal symptoms. Such curves enable anisocytosis, initially noted on microscopy, to be compared objectively with a normal curve. This patient had deficiency of $B_{12}$, folate, and iron. (C) Gross red cell anisocytosis is shown in a case of $B_{12}$ deficiency associated with folic acid deficiency before treatment. The skew to left indicates large numbers of microcytic cells and is an unusual feature in cases where iron deficiency is not present. (D) A case of coeliac disease with $B_{12}$, folate, and iron deficiency. On microscopy two distinct populations were present in the pretreatment phase. This appearance was confirmed and shown to be a definite bimodal red cell distribution. (E) A case of coeliac disease presenting with macrocytic anaemia manifesting a partial bimodal distribution with gross anisocytosis. $B_{12}$, folate, and iron were deficient; the diagnosis was confirmed on jejunal biopsy. 
We thank Dr T. Bird, Dr R. B. Thompson, and Dr W. Walker for their helpful suggestions in the preparation of this manuscript, and R. A. McNay and P. A. Clarke for statistical advice.

\section{References}

Bentley, S. A. and Lewis, S. M. (1975). The use of an image analysing computer for the quantitation of red cell morphological characteristics. Brit. J. Haemat., 29, 81-88.

Bessman, J. D. and Johnson, R. K. (1975). Erythrocyte volume distribution in normal and abnormal subjects. Blood, 46, 369-379.

Britt, R. P., Bolton, F. G., Cull, A. C., and Spray, G. H. (1969). Experience with a simplified method of radioisotopic assay of serum vitamin $\mathbf{B}_{12}$. Brit. J. Haemat., 16457.

Chanarin, I. (1969). The Megaloblastic Anaemias, p. 343. Blackwell, Oxford.
England, J. M. and Down, M. C. (1974). Red cell volume distribution curves and the measurement of anisocytosis. Lancet, 1, 701-703.

Herbert, V. (1966). Aseptic addition method for Lactobacillus casei assay of folate activity in human serum. J. clin. Path., 19, 12-16.

Hughes-Jones, N. C., Norley, I., Young, J. M. S. and England, J. M. (1974). Differential white cell counts by frequency distribution analysis of cell volumes. J. clin. Path., 27, 623-625.

Lushbaugh, C. C., Maddy, J. A. and Basmann, N. J. (1962). Electronic measurement of cellular volumes. I. Calibration of the apparatus. Blood, 20, 233-248.

Technicon Autoanalyser Methodology. File N62P. Serum iron measurement.

Ur, A. and Lushbaugh, C. C. (1968). Some effects of electrical fields on red blood cells with remarks on electronic red cell sizing. Brit. J. Haemat., 15, 527-538.

van der Wal, G. (1972). A modified method for the determination of total iron binding capacity. Clin. chim. Acta, $36,570-571$. 